\title{
Wind contribution to yearly silver fir (Abies alba Mill.) compression wood development in the Romanian Carpathians
}

\author{
Florin Dinulica, Viorela Marcu, \\ Stelian Alexandru Borz, Maria- \\ Magdalena Vasilescu, Ion Catalin \\ Petritan
}

\begin{abstract}
Since the 1950s, wind has represented one of the main disturbances to forest ecosystems in Europe, causing an increase in the frequency and amount of trees uprooted or broken by wind. Such phenomenon has also increased the incidence of compression wood in the xylem of remnant trees, thus leading to a general decrease in timber quality. In this study, we aimed to determine how wind regime affects the incidence of compression wood by reconstructing its chronology at both inter- and intra-annual scale using dendroclimatic methods. Six silver fir stands at different elevations were selected in central Romania, and compression wood time series were obtained from both increment cores from standing trees and radial discs from felled trees. Wood-structure variables were statistically analyzed as time series, while fluctuations of wind frequency and speed over the period 1921-present were reconstructed based on meteorological data. The structural response of sampled trees to wind was assessed based on the annual fluctuation in the frequency and intensity of compression wood. Results showed that the incidence of compression wood in the time series was synchronized with the intensity of the wind, rather than its duration. Wind regime in December of the preceding calendar year was significantly correlated with the frequency of compression wood, whereas its intensity was significantly correlated with wind load of previous September. The response of cambium to the wind stimulus increased with distance from the tree collar, peaking in the section at the base of the crown. At a decennial scale, only high-intensity wind stress triggered structural responses in the studied trees. Wind effects on xylogenesis in the analyzed stands increased over the last decades as a consequence of the local forest management. A better understanding of the structural response of forest trees to wind regime may explain how individual and groups of trees compete for stability and can help to improve forest management strategies in windy regions.
\end{abstract}

Keywords: Reaction Wood, Wind Regime, Dendroclimatology, Silver Fir, Carpathian Mountains

(Gruber et al. 2009). In general, wind speed increases logarithmically with elevation (Geiger et al. 2003), and the higher content of compression wood in high-altitude tree populations indicate their better adaptation to severe wind regimes as compared with low-altitude populations (Duncker \& Spiecker 2005).

Plants exhibit phenotypic plasticity to wind, due to their almost continuous interaction with the moving air (Read \& Stokes
Transilvania University of Brasov, Faculty of Silviculture and Forest Engineering, Department of Forest Engineering, Forest Management and Terrestrial Measurements, Sirul Beethoven 1, 500123 Brasov (Romania)

@ Ion Catalin Petritan (petritan@unitbv.ro)

Received: Jun 12, 2015 - First Accepted: Dec 09, 2015 - Final Acceptance: Sep 14, 2016

Citation: Dinulica F, Marcu V, Borz SA, Vasilescu M-M, Petritan IC (2016). Wind contribution to yearly silver fir (Abies alba Mill.) compression wood development in the Romanian Carpathians. iForest 9: 927-936. - doi: 10.3832/ifor1742-008 [online 2016-10-02]

Communicated by: Enrico Marchi
2006). Wind affects the shape and structure of tree stems (Robertson 1990, Enoos 1999) by determining anisotropy in the radial growth, resulting in the oval shape of the stem cross section, whose orientation depends on the prevailing winds (Macdonald \& Hubert 2002). It has been reported that the base trunk geometry in silver fir is affected by mountain breeze in the upper third of mountain slopes and by the valley breeze in the lower third (Dinulica 2008). Compression wood formation and its positioning around the stem is influenced by the direction of prevailing winds and trunk inclination (Low 1964, Duncker \& Spiecker 2008), thus affecting physical, chemical, mechanical, and technological characteristics of the timber (Macdonald \& Hubert 2002, Wimmer \& Johansson 2014).

Dendrochronological analyses have demonstrated the utility of compression wood in reconstructing the wind-load history of trees (Pillow 1931, Schweingruber 2007) and dating geomorphological events such as snow avalanches, landslides and earthquakes (Butler \& Sawyer 2008, Stoffel \& Bollschweiler 2008), as well as major 


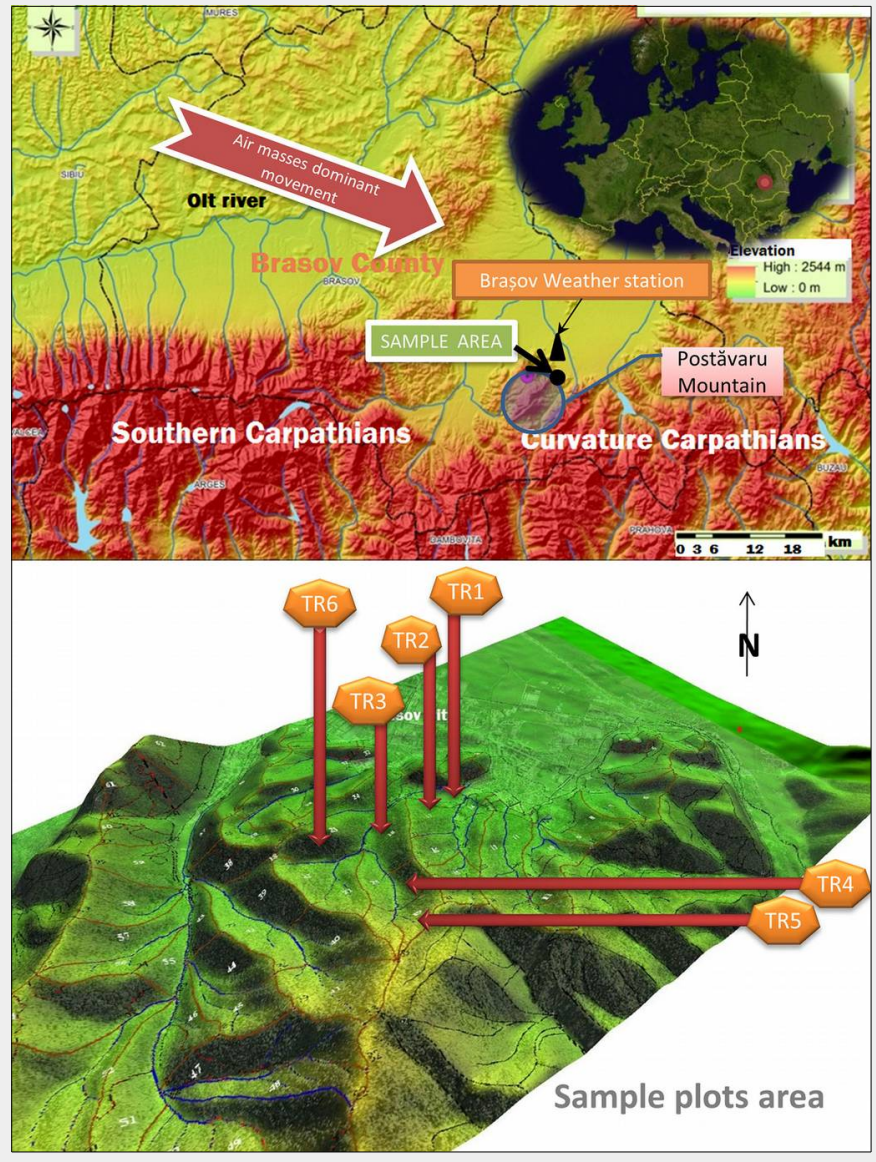

Fig. 1 - Geographic location of the study site (upper panel) and distribution of the sample plots over the study area (lower panel).

windstorms and snowfall (Cherubini et al. 1996). Previous studies (e.g., Panayotov \& Yurukov 2005) analysed the incidence of compression wood as time series, but they did not detrend and did not calibrate them in relation to wind climate. Although compression wood shows a variable morphoanatomical intensity (Shelbourne \& Ritchie 1968, Harris 1977, Dinulică 2005, 2008), this was not rendered by the compression wood chronologies drawn up until now.
Dendroclimatic studies on compression wood are quite rare, being mainly restricted to areas characterized by strong winds (Grissino-Mayer et al. 2010). In this study, we investigated how wind affects compression wood in trees of a temperate forest in the Romanian Carpathians, at the eastern limit of the beech-silver fir vegetation zone in Europe. We primarily aimed at reconstructing the wind regime at the study sites based on xylem characteristics

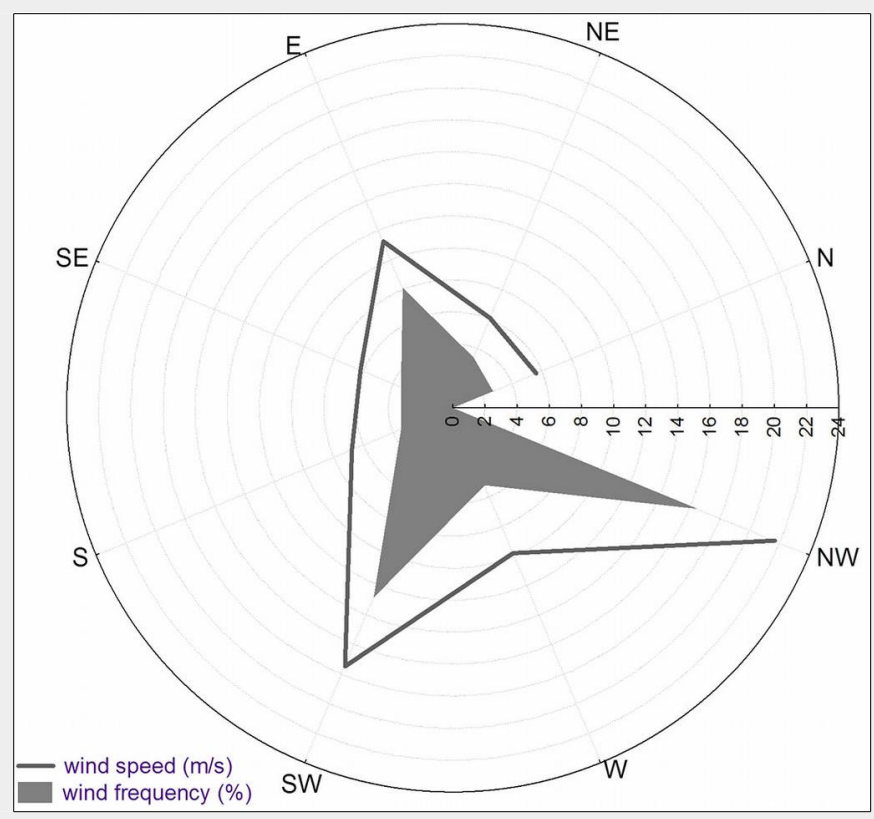

Fig. 2 - Prevalent wind directions in the study area (multiannual values over the 19642004 period). Data source: Brasov meteorological station, Romania $\left(45^{\circ} 40^{\prime} \mathrm{N}, 25^{\circ} 37^{\prime}\right.$ $\mathrm{E}$, elevation $528 \mathrm{~m}$ a.s.l.) of silver fir trees. The main objectives of this study were to: (i) identify the main wind patterns by studying the compression wood in silver fir and reconstruct the compression wood chronology at an inter- and intra-annual scale using dendroclimatic methods; (ii) identify the tree height at which trunks are most sensitive to wind stimuli; and (iii) evaluate how anthropogenic factors affect the interaction between wind and xylem structure.

\section{Material and methods}

\section{Site description}

The study was carried out in the premountainous region of the Postavaru Mountains, near Braşov (central Romania Fig. 1). The area is located at the crossroads of different climatic regions (oceanic: West European, South European; continental: East European), and is characterized by a mild temperate-continental climate (Mihai 1975). The dominant wind direction in the area is north-west (Fig. 2), with a moderate influence of local reliefs (Marcu-Huber 2001). The thermic regime is influenced by frequent radiative orographic inversions, with mean annual temperature of $7.5{ }^{\circ} \mathrm{C}$ and $7.8^{\circ} \mathrm{C}$ at 508 and $700 \mathrm{~m}$ a.s.l., respectively. The annual rainfall is $815 \mathrm{~mm}$ at the lowest elevations, $840 \mathrm{~mm}$ at $700 \mathrm{~m}$ a.s.l., and $940 \mathrm{~mm}$ at $1000 \mathrm{~m}$ (Marcu et al. 2006). Snow cover lasts for 70 days at the lowest elevations and for 116 days at $1000 \mathrm{~m}$ a.s.l., while the growing season spans 167 days year ${ }^{-1}$ on average at the lowest elevations (Mihai 1975). The soils are fertile (with the exception of the TR5 plot, where a modest volume of soil limits the tree growth) and sometimes hydromorphic (as in the case of the TR1 and TR2 sample plots - Tab. 1).

Silver fir (Abies alba Mill.) is widespread in the study region due to favorable soil and climatic conditions (mainly on shaded exposures) and to long-time exploitation of oak trees. Silver fir crowns in the region frequently exhibit forking, mainly at higher altitudes due to the thermic inversion (Dinulica 2008).

\section{Stand and sampling plots characteristics}

The studied stands were uneven-aged or two-storey beech-silver fir mixed forests intensively managed by selective cutting, which was enforced after 1961. Harvest intensity varied in time and from one area to another.

We established six sampling plots (TR1, $T_{2}, T_{3}, T R 4, T R 5, T R 6$ ) over a wide range of vegetation conditions (Tab. 1). Most of the chosen locations were subject to windthrows, which caused uprooting or breaking of trees and led to a recent loss of trees in the TR2 plot. Uprooting caused by wind allowed the state of the roots to be examined.

We selected a total of 66 individual trees (Tab. 2) with height above the upper quartile (top canopy layer) and straight or low- 
inclination $\left(<6^{\circ}\right)$ stem showing no or weak curvature, to avoid any influence of additional stimuli on annual records of compression wood in the basal trunk. Sampled trees were of 70 to 290 years old, with breast height diameter ranging between 35 and $98 \mathrm{~cm}$, and height ranging between 24.5 and $44.2 \mathrm{~m}$.

Two increment cores were extracted at the breast height from each sampled tree. One core was extracted in the direction of the prevailing wind, as inferred from the trunk geometry, while the second was extracted orthogonally to the first (Dinulica 2008). A total of 111 increment cores were processed after extraction (Tab. 2).

Sixty-three discs were collected in the same period from 25 trees felled in the harvested blocks near the TR2, TR3, and TR7 sample plots. Felled trees were crosscut at different distances from the collar $(0,4,8$, 12, 16, 20, $28 \mathrm{~m}$ - Tab. 2). On each disc, the largest diameter and its orthogonal diameter were chosen for measurements. Data from each sector (0-3.9 m; 4-7.9 m; 8-11.9 m; $12-15.9 \mathrm{~m} ; 16-19.9 \mathrm{~m} ; 20-27.9 \mathrm{~m} ; \geq 28 \mathrm{~m}$ ) were pooled together, thus each height sector was represented by a mean axial series of growth rings (TROY-1 to TROY-7). To assess how anthropogenic factors interacts with the influence of wind on xylogenesis, we selected two series from sites subject to different human pressure (TROI-E and TROI-F - Tab. 2).

\section{Compression wood indices}

The frequency of occurrence and the intensity of compression wood were examined in the sampled material. Two numerical-chronological series were used for each increment core and for each disc radius. The presence/absence of defects (compression wood) in a specific year along the series was recorded as 1/0, respectively. The intensity of the compression wood was assessed based on color and thickness of latewood, using the following numerical codes: (0) normal wood (the latewood was more yellowish than earlywood); (1) mild compression wood (the latewood ranged from light orange to red-yellowish); (2) moderate compression wood (latewood color was brown-yellowish-reddish); (3) severe compression wood (latewood color ranged from brown-reddish-yellowish to dark brown, spanning more than $50 \%$ of the width of growth rings - Dinulica 2008). The annual frequency of compression wood $\left(Y C W F_{i}\right)$ was determined for each plot as the percent ratio between the number of cores presenting compression wood in the $i$-th calendar year and the total number of cores in which the calendar year $i$ was represented. The annual degree of severity of compression wood $\left(Y C W D S_{\mathrm{i}}\right)$ was determined from the same samples as the arithmetic mean of compression wood intensity (for compression wood that was formed in the $i$-th year in all the cores from the sample plot in which year $i$ was represented). As compression wood did not

Tab. 1 - Main environmental characteristics of the sample plots. (*): Soil classification according to WRB (1998); (APL): Anthropogenic Pressure Level, based on four level defined according to forest management plans (1950) and general silvicultural principles (Helliwell 2004, Nicolescu 2014).

\begin{tabular}{lcccccll}
\hline Plot & Long & Lat & Elev. (m) & Aspect & Slope $\left({ }^{\circ}\right)$ & Soil type* & APL \\
\hline TR1 & $25^{\circ} 37^{\prime} \mathrm{E}$ & $45^{\circ} 37^{\prime} \mathrm{N}$ & 650.7 & - & 2 & Dystric Gleysol & Low \\
TR2 & $25^{\circ} 37^{\prime} \mathrm{E}$ & $45^{\circ} 36^{\prime} \mathrm{N}$ & 697.3 & $\mathrm{SE}$ & 27 & Stagni-albic Luvisol & Increased \\
TR3 & $25^{\circ} 36^{\prime} \mathrm{E}$ & $45^{\circ} 37^{\prime} \mathrm{N}$ & 765.5 & $\mathrm{NV}$ & 16 & Dystric Cambosol & Moderate \\
TR4 & $25^{\circ} 36^{\prime} \mathrm{E}$ & $45^{\circ} 36^{\prime} \mathrm{N}$ & 819.3 & V & 26 & Dystric Cambosol & Increased \\
TR5 & $25^{\circ} 36^{\prime} \mathrm{E}$ & $45^{\circ} 36^{\prime} \mathrm{N}$ & 948.4 & NV & 36 & Lepti-dystric Cambisol Moderate \\
TR6 & $25^{\circ} 36^{\prime} \mathrm{E}$ & $45^{\circ} 37^{\prime} \mathrm{N}$ & 798.3 & $\mathrm{~S}$ & 25 & Dystric Cambosol & High \\
\hline
\end{tabular}

Tab. 2 - Tree sample size and labels of the time series analyzed in this study. (TROI): increment core series; (TROY): axial growth-ring series.

\begin{tabular}{lllccr}
\hline $\begin{array}{l}\text { Sampled } \\
\text { trees }\end{array}$ & $\begin{array}{l}\text { Source plot / } \\
\text { Height sector }\end{array}$ & $\begin{array}{l}\text { Growth-ring } \\
\text { series label }\end{array}$ & $\begin{array}{c}\boldsymbol{N} \text { trees/ } \\
\text { discs }\end{array}$ & $\begin{array}{r}\boldsymbol{N} \text { increment } \\
\text { cores/radii }\end{array}$ & $\begin{array}{c}\boldsymbol{N} \\
\text { measured } \\
\text { rings }\end{array}$ \\
\hline Standing & TR1 & TROI-A & 13 & 25 & 883 \\
trees & TR2 & TROI-B & 7 & 14 & 1361 \\
& TR3 & TROI-C & 9 & 18 & 1831 \\
& TR4 & TROI-D & 12 & 15 & 1128 \\
& TR5 & TROI-E & 12 & 17 & 1774 \\
& TR6 & TROI-F & 13 & 22 & 1962 \\
& - & TROI (full core's dataset) & 66 & 111 & 8939 \\
Felled & $0-3.9 m$ & TROY-1 & 6 & 24 & 3425 \\
trees & $4-7.9 m$ & TROY-2 & 7 & 26 & 3623 \\
& $8-11.9 m$ & TROY-3 & 12 & 47 & 5286 \\
& $12-15.9 m$ & TROY-4 & 7 & 27 & 2354 \\
& $16-19.9 \mathrm{~m}$ & TROY-5 & 11 & 43 & 2982 \\
& $20-27.9 \mathrm{~m}$ & TROY-6 & 10 & 40 & 2703 \\
& $\geq 28 \mathrm{~m}$ & TROY-7 & 10 & 40 & 1479 \\
\hline
\end{tabular}

occur in some of the sample plots in certain seasons, $Y C W D S$ was not always represented a continuous chronological series, which raised some problems during standardization.

To generate the axial growth-ring series (TROY), data from the series obtained for individual radii on each disc were assembled in mean series over each disc, which in turn were assembled in mean series over each height sector. For quantification purposes, the four measured radii formed a unique binary series, in which value 1 indicated the annual presence of a defect on at least one of the radii. The mean series of $Y C W F$ of each sector was used to calculate the relative frequency of defects for all of the series belonging to that sector.

\section{Building chronologies}

Measurement of growth rings, the development of raw series of the growth rings, and their cross-dating were performed using the WinDENDRO ${ }^{\oplus}$ image-analysis system, the Density 2006c version (WinDENDRO 2007). Growth rings were scanned, delineated and measured on digital images. A local master chronology was not available, therefore a reference series was created using 41 growth samples collected from dominant and codominant trees from a different stand $\left(45^{\circ} 36^{\prime} \mathrm{N}, 25^{\circ} 37^{\prime} \mathrm{E}\right.$; elevation $719 \mathrm{~m}$ a.s.l.). The following wood struc- tural indices were recorded from chronologies: $T R W$ - total ring width; $E W W$ - earlywood width; $L W W$ - latewood width; $E W P$ - earlywood percentage (of the total ring width); $L W P$ - latewood percentage.

Because a strong intraserial dependency was observed, the AutoRegressive Integrated Moving Average (ARIMA) model was used for the standardization of raw series (Box et al. 2008). The model's parameters (autoregressive and moving average parameters, number of differencing passes) were determined using the Melard procedure (Box et al. 2008). For each series, the fitting procedure yielding a reliable ARIMA process after modeling was chosen.

Time series were prepared for standardization by smoothing. Negative-exponential or natural-logarithmic smoothing were used, and the series that were resistant to smoothing models were power-transformed or smoothed using the mobile movingaverage method.

\section{Climate data}

Meteorological records were obtained from the meteorological station in Brasov $\left(45^{\circ} 40^{\prime} \mathrm{N}, 25^{\circ} 37^{\prime} \mathrm{E}\right.$, elevation $528 \mathrm{~m}$ a.s.l.), which is located in the vicinity of the sampled plots. Wind, temperature, and precipitation data from 1921 to present were used for the purposes of this study. Wind direc- 
Tab. 3 - Descriptive statistics of the non-detrended growth-ring average series. (Avg): average; (CV): coefficient of variation.

\begin{tabular}{llll}
\hline \multirow{2}{*}{$\begin{array}{l}\text { Structural } \\
\text { index }\end{array}$} & Statistics & Series & \\
\cline { 2 - 4 } & & TROI & TROY \\
\hline CRW & Cvg & $1825-2007$ & $1866-2006$ \\
{$[\mathrm{~mm}]$} & Max & 3.790 & 1.977 \\
& Min & $0.703(1977)$ & $3.541(1914)$ \\
& CV & 31.92 & $0.977(2003)$ \\
\hline LWW & Avg & 0.683 & 24.03 \\
{$[\mathrm{~mm}]$} & Max & $1.134(1998)$ & 0.617 \\
& Min & $0.232(1849)$ & $1.092(1881)$ \\
& CV & 31.93 & $0.286(2003)$ \\
LWP & Avg & 35.98 & 26.35 \\
{$[\%]$} & Max & $44.30(1899)$ & 32.93 \\
& Min & $24.28(1853)$ & $43.08(1880)$ \\
& CV & 8.98 & $23.55(1928)$ \\
YCWF & Avg & 22.58 & 9.83 \\
& Max & 11.76 \\
& Min & $69.50(1907)$ & $34.43(1880)$ \\
& CV & $4.17(2006)$ & $0(1860,1861,1863-1865)$ \\
YCWDS & Avg & 52.68 & 52.43 \\
& Max & 1.85 & 1.72 \\
& Min & $3.00(1902)$ & $2.33(1953)$ \\
& CV & $1.05(1985)$ & $1.17(1986)$ \\
\hline
\end{tabular}

tion and intensity (speed) was recorded four times a day using an aerovane mounted $10 \mathrm{~m}$ above the ground. Wind indices were calculated from raw data and time series were constructed based on annual and monthly mean index values. Wind regime was defined using the following indices:

- $Y C F / M C F$ : annual/monthly average frequency of calm periods;

- $Y W F / M W F$ : annual/monthly average frequency of windy periods;

- YWS/MWS: annual/monthly average wind speed, weighted by the frequency in the eight reference cardinal directions;

- $S W F$ : average number of days with high speed winds (speed $\geq 11 \mathrm{~m} \mathrm{~s}^{-1}$, according to 6-9 classes of the Beaufort scale - Lutgens \& Tarbuck 2013) classified by: (i) the minimum daily frequency (at least one case in four) of the meteorological recordings - SWF1 index; and (ii) the average daily speed of the wind - SWF2 index.

The values of these indices (hereafter, wind variables) were used to construct wind series. The difference in length of the series reflects the different number of observations in period considered and the improvement of recording instruments over time.

\section{Data analysis}

Structural indices ( $T R W, E W W, L W W, L W P$, $Y C W D S$ and $Y C W F$ ) and the variation of the analyzed climatic factors were organized as time series and analyzed using time series statistical procedures (Box et al. 2008). First, the hypothesis of variables randomness was tested using the mean square successive difference test for serial randomness (Sheskin 2004). Second, descriptive statistics were computed and interpreted for all of the variables used to test the relationship between wood structure and environmental variables. Third, we attempted to isolate the signal, i.e., to identify the co-variation of time series from a particular plot or height sector. Specific dendrochronological statistical procedures were used to quantify the signal strength and the statistical confidence of chronologies (Cook \& Briffa 1992).

The fluctuation in the values of structural indices accounted for by environmental factors was verified using dendrochronological statistics of the signal strength (Cook \& Briffa 1992, Cook \& Pederson 2011). For example, we verified the mean sensitivity of the mean chronology (MSc), ESR (Edmund Schulman's R), and the family of inter-serial average correlation coefficients RBAR (RTOT: the mean correlation within and between trees and discs; RWT: the mean correlation within trees and discs; RBT: the mean correlation between trees and discs; REFF: the effective chronology signal REFF). The statistical confidence of chronologies was assessed using the expressed population signal (EPS). The confidence intervals for the detrended series are presented using the standard error (SE).

The relationship between wood-structure variables and climatic predictors was verified using the Pearson's product-moment correlation coefficient $(r)$. Wind influence on structural chronologies was assessed after removing the influence of the other environmental variables (rainfall and temperature). The contribution of the predictor to the annual oscillations in wood structure was estimated using the determination coefficient $\left(R^{2}\right)$.

All statistical analyses were carried out using the software package STATISTICA ${ }^{\oplus} \mathrm{v}$. 12.0 (StatSoft Inc, Tulsa, OK, USA).

\section{Results}

Annual variation of wood structural variables

Significant differences between consecutive growth rings belonging to average non-detrended series (TROI and TROY) were found using the $t$-test $(p<0.0001)$ for each of the five analyzed structural indices (TRW, $L W W, Y C W F, Y C W D S, L W P$ ). The null hypothesis of random fluctuation over time was rejected (calculated absolute $Z$ > critical $0.05 \mathrm{Z}$ value) for all indices except LWP. Moreover, most structural indices exhibited a cyclic behavior over time (calculated $Z=6.74-11.81>$ critical $Z=1.65$ ).

$Y C W F$ was the structural index with the largest contribution to data heterogeneity (CV - Tab. 3). The wide range of values detected for all structural parameters highlights the remarkable plasticity of the secondary xylem. The proximity of a multiannual maxima of $Y C W F$ and $Y C W D S$ (for the years 1907 and 1905, respectively) suggested the occurrence of a possible strong wind event, though in general the two average series were asynchronous. The TROI mean series of $Y C W F$ had no null values, i.e., the formation of compression wood was continuous over the entire length of the series. The 1847-1860 time sequence was missing in most individual series.

\section{Statistical features of structural series}

A preliminary examination of the internal variability of structural indices was performed using the dendrochronological statistics MS, ESR, and PACF (Tab. 4). The highest ACF range between consecutive growth rings was recorded in the TROI series of the $Y C W D S$. The lowest ACF value was recorded in the last trunk sector, providing the first evidence of signal quality in the bole extremity. The ACF square indicated that the information transfer from one season to another (via YCWDS) was twice as high for TROI vs. TROY series. Similarly, the preceding growth season explained $74 \%$ of current $Y C W F$ in the lower sector (4 $\mathrm{m}$ above the ground), but only $31.5 \%$ in the upper sectors. After data filtering with ARIMA, signal relevance (EPS threshold value $=0.85$ ) supported the use of TROI-A and TROY-7 series for TRW and $L W W$ indices, respectively.

The time series of wind-related variables ( $S W F$ and YWS) showed fluctuations that were consistent with those observed for wood structural indices (YCWF and $Y C W D S$ ). Moreover, the observed coefficients of inter-annual variation were higher than the inter-monthly coefficients, i.e., the fluctuation of wind regime over years is more pronounced than its monthly variation (Tab. 5).

Cluster analysis of wood structural indices for the trunk base sector revealed a discrepancy between the $Y C W F$ average time series and those of the other structural indices (Fig. 3), while YCWDS fluctuations 
Tab. 4 - Signal properties of the examined time series. (SI): Structural index; (SS): Status of standardization; (DS): Dendrochronological statistics; (*) first-order autocorrelation.

\begin{tabular}{|c|c|c|c|c|c|c|c|c|c|c|c|c|c|c|c|}
\hline \multirow[b]{2}{*}{ SI } & \multirow[b]{2}{*}{ SS } & \multirow[b]{2}{*}{ DS } & \multicolumn{6}{|c|}{ Core growth-ring series (TROI) } & \multicolumn{7}{|c|}{ Axial growth-ring series (TROY) } \\
\hline & & & $\begin{array}{l}\stackrel{\leftarrow}{1} \\
\stackrel{1}{0} \\
\stackrel{\alpha}{F}\end{array}$ & 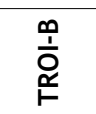 & 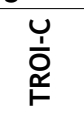 & $\begin{array}{l}\text { 足 } \\
\text { ō } \\
\text { op }\end{array}$ & 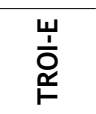 & $\begin{array}{l}\frac{4}{1} \\
\frac{1}{\circ} \\
\stackrel{2}{F}\end{array}$ & $\begin{array}{l}\bar{I} \\
\text { خे } \\
\stackrel{2}{1}\end{array}$ & 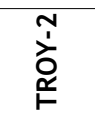 & 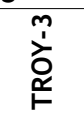 & 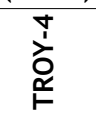 & 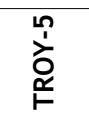 & 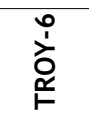 & 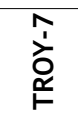 \\
\hline \multirow[t]{7}{*}{ TRW } & \multirow{3}{*}{$\begin{array}{l}\text { Before } \\
\text { detrending }\end{array}$} & MS & 0.145 & 0.160 & 0.130 & 0.137 & 0.129 & 0.141 & 0.178 & 0.156 & 0.137 & 0.165 & 0.153 & 0.153 & 0.185 \\
\hline & & ESR & 0.597 & 0.759 & 0.747 & 0.770 & 0.806 & 0.693 & 0.813 & 0.776 & 0.682 & 0.760 & 0.660 & 0.664 & 0.740 \\
\hline & & ACF_1* & 0.815 & 0.921 & 0.867 & 0.838 & 0.932 & 0.767 & 0.827 & 0.823 & 0.869 & 0.877 & 0.719 & 0.774 & 0.329 \\
\hline & \multirow{4}{*}{$\begin{array}{l}\text { ARIMA } \\
\text { chronologies }\end{array}$} & MS & 0.245 & 0.269 & 0.245 & 0.307 & 0.234 & 0.236 & 0.266 & 0.241 & 0.220 & 0.213 & 0.268 & 0.221 & 0.264 \\
\hline & & REFF & 0.560 & 0.331 & 0.038 & 0.158 & 0.085 & 0.237 & 0.446 & 0.371 & 0.286 & 0.181 & 0.200 & 0.327 & 0.377 \\
\hline & & EPS & 0.943 & 0.776 & 0.299 & 0.674 & 0.527 & 0.802 & 0.829 & 0.805 & 0.828 & 0.607 & 0.733 & 0.829 & 0.858 \\
\hline & & SE & 0.184 & 0.309 & 0.327 & 0.277 & 0.276 & 0.242 & 0.304 & 0.300 & 0.244 & 0.342 & 0.270 & 0.259 & 0.250 \\
\hline \multirow[t]{7}{*}{$L W W$} & \multirow{3}{*}{$\begin{array}{l}\text { Before } \\
\text { detrending }\end{array}$} & MS & 0.189 & 0.230 & 0.175 & 0.192 & 0.199 & 0.187 & 0.265 & 0.225 & 0.182 & 0.247 & 0.231 & 0.266 & 0.257 \\
\hline & & ESR & 0.554 & 0.785 & 0.618 & 0.660 & 0.693 & 0.581 & 0.810 & 0.740 & 0.603 & 0.729 & 0.635 & 0.684 & 0.702 \\
\hline & & ACF_1 & 0.779 & 0.814 & 0.733 & 0.756 & 0.865 & 0.605 & 0.663 & 0.641 & 0.672 & 0.671 & 0.328 & 0.611 & 0.248 \\
\hline & ARIMA & MS & 0.354 & 0.419 & 0.303 & 0.331 & 0.042 & 0.352 & 0.082 & 0.064 & 0.081 & 0.078 & 0.076 & 0.109 & 0.068 \\
\hline & \multirow{3}{*}{ chronologies } & REFF & 0.423 & 0.263 & 0.067 & 0.121 & 0.151 & 0.139 & 0.236 & 0.275 & 0.246 & 0.201 & 0.190 & 0.295 & 0.431 \\
\hline & & EPS & 0.905 & 0.714 & 0.393 & 0.602 & 0.681 & 0.677 & 0.650 & 0.659 & 0.797 & 0.638 & 0.721 & 0.807 & 0.883 \\
\hline & & SE & 0.211 & 0.324 & 0.322 & 0.283 & 0.266 & 0.257 & 0.357 & 0.348 & 0.251 & 0.338 & 0.271 & 0.266 & 0.239 \\
\hline \multirow[t]{2}{*}{ YCWF } & \multirow{2}{*}{$\begin{array}{l}\text { Before } \\
\text { detrending }\end{array}$} & MS & 0.514 & 0.704 & 0.220 & 0.625 & 0.423 & 0.401 & 0.673 & 0.558 & 0.213 & 0.543 & 0.537 & 0.373 & 0.465 \\
\hline & & ACF_1 & 0.671 & 0.718 & 0.765 & 0.728 & 0.805 & 0.692 & 0.643 & 0.718 & 0.610 & 0.628 & 0.507 & 0.752 & 0.497 \\
\hline \multirow[t]{2}{*}{ YCWDS } & \multirow{2}{*}{$\begin{array}{l}\text { Before } \\
\text { detrending }\end{array}$} & MS & 0.174 & 0.156 & 0.164 & 0.116 & 0.142 & 0.127 & 0.118 & 0.152 & 0.182 & 0.158 & 0.176 & 0.143 & 0.261 \\
\hline & & ACF_1 & 0.667 & 0.586 & 0.649 & 0.777 & 0.719 & 0.735 & 0.748 & 0.643 & 0.428 & 0.698 & 0.536 & 0.624 & 0.075 \\
\hline
\end{tabular}

Tab. 5 - Descriptive statistics of the non-detrended time series of wind-related variables. (Avg): average; (ME): median; (MAvg): multiannual average; (CV): Coefficient of inter-annual/ inter-monthly variation.

\begin{tabular}{|c|c|c|c|c|c|c|}
\hline \multirow{3}{*}{$\begin{array}{l}\text { Wind } \\
\text { variable }\end{array}$} & \multirow{3}{*}{$\begin{array}{l}\text { Common } \\
\text { interval }\end{array}$} & \multicolumn{5}{|c|}{ Statistics } \\
\hline & & \multirow{2}{*}{ Avg } & \multirow{2}{*}{ ME } & \multicolumn{2}{|c|}{ Range } & \multirow{2}{*}{$\begin{array}{l}\mathrm{CV} \\
\text { (\%) }\end{array}$} \\
\hline & & & & Min (year/month) & Max (year/month) & \\
\hline YCF & $\begin{array}{c}87 \\
(1921-2007)\end{array}$ & 35.9 & 38.9 & $\begin{array}{c}2.0 \\
(1954,1955)\end{array}$ & $\begin{array}{l}65.6 \\
(1951)\end{array}$ & 40.9 \\
\hline MCF & $\begin{array}{c}44 \\
(1964-2007)\end{array}$ & 43.7 & 43.8 & $\begin{array}{c}34.8 \\
\text { (April MAvg) } \\
9.2 \\
\text { (July 2006) }\end{array}$ & $\begin{array}{c}53.7 \\
\text { (January MAvg) } \\
94.9 \\
\text { (December 1994) }\end{array}$ & 28.9 \\
\hline YWS & $\begin{array}{c}67 \\
(1941-2007)\end{array}$ & 3.5 & 3.4 & $\begin{array}{c}1.6 \\
(1949)\end{array}$ & $\begin{array}{c}5.4 \\
(1998)\end{array}$ & 36.6 \\
\hline MWS & $\begin{array}{c}44 \\
(1964-2007)\end{array}$ & 4.3 & 4.3 & $\begin{array}{c}3.5 \\
\text { (February MAvg) } \\
0.3 \\
\text { (August 1984) }\end{array}$ & $\begin{array}{c}4.9 \\
\text { (March and November MAvg) } \\
9.2 \\
\text { (January 1976) }\end{array}$ & 30.5 \\
\hline SWF1 & $\begin{array}{c}87 \\
(1921-2007)\end{array}$ & 15.7 & 16.0 & $\begin{array}{c}0 \\
(1944)\end{array}$ & $\begin{array}{c}63 \\
(1974)\end{array}$ & 69.7 \\
\hline SWF2 & $\begin{array}{c}35 \\
(1973-2007)\end{array}$ & 2.8 & 2.0 & $\begin{array}{c}0 \\
(1987,1989,1996,1997,1999, \\
2004-2007)\end{array}$ & $\begin{array}{c}11 \\
(1981)\end{array}$ & 109.6 \\
\hline
\end{tabular}

from the residual series was fairly consistent with the $L W W$ fluctuations.

\section{Wind regime as predictor}

The ability of the wood-structure time series to reflect fluctuations in wind-related variables is shown in Fig. 4. Correlation coefficients between detrended time series of wind-related parameters and structural indices greatly varied across samples, despite their geographical concordance. The largest range of correlation coefficients was detected for $S W F 1$ ( $r$ range: 1.305) and for $Y C W D S$ ( $r$ range: 0.900).

The strongest correlations with the wind explanatory variables $(r=-0.734, p<0.001)$ was found for YCWDS and SWF2 in the TROY-1 series. The trunk height sectors 1, 2, and 3 (up to $12 \mathrm{~m}$ above the ground) seems to be more sensitive to wind (for example,

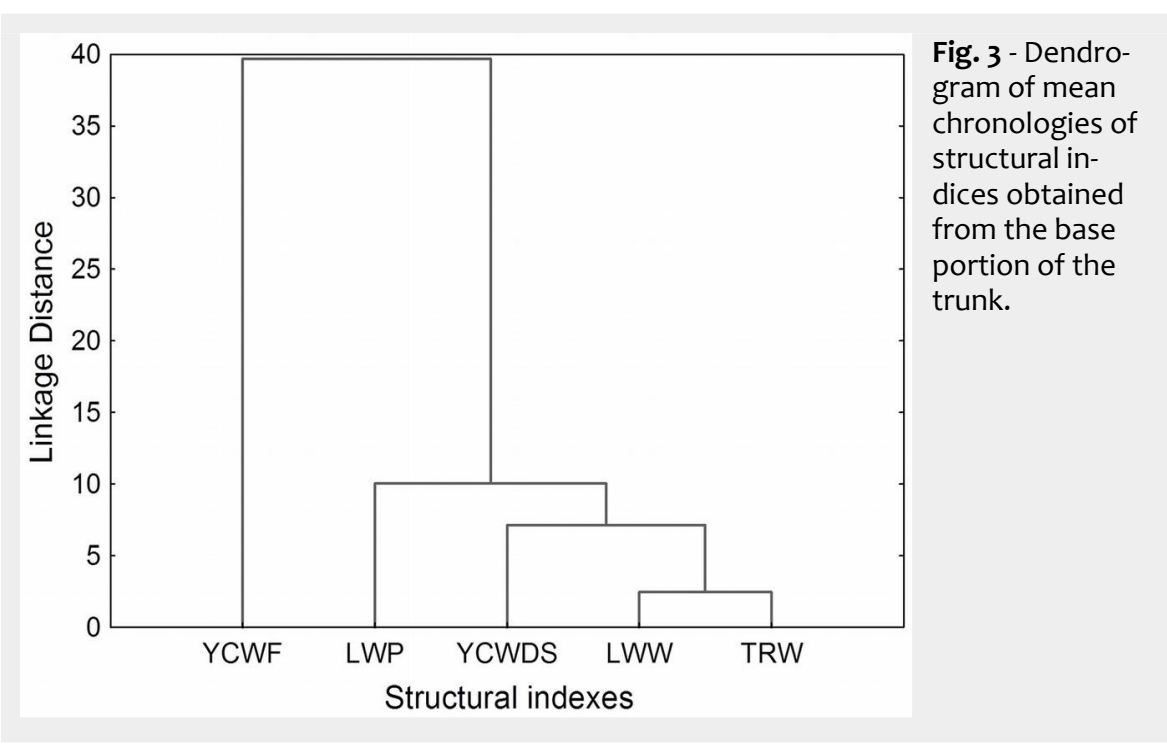



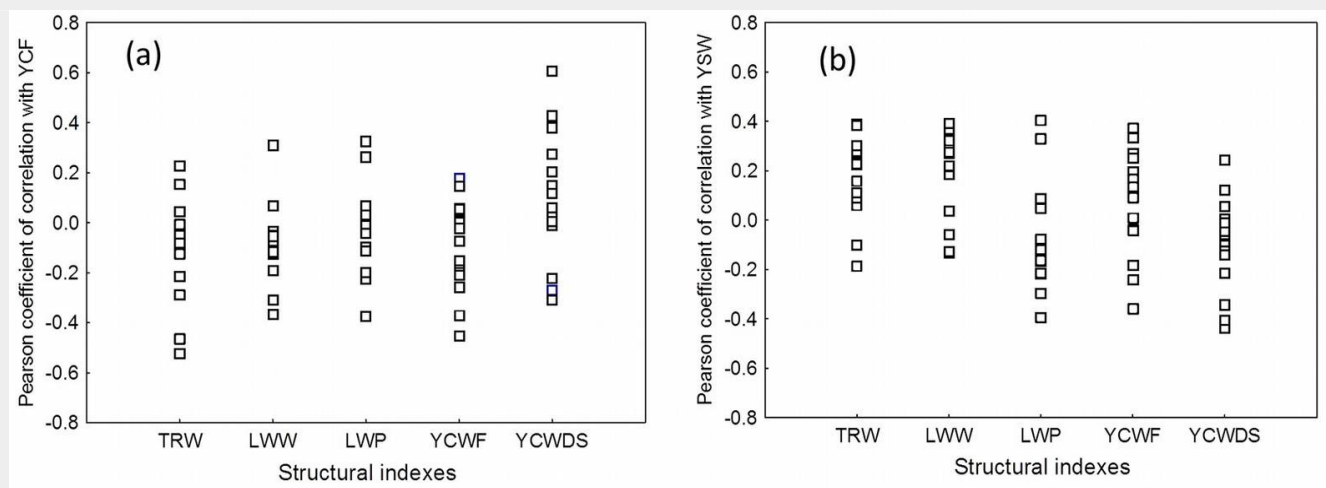

Fig. 4 - Pearson's correlation coefficients between windrelated variables and structural indices in the detrended time series analyzed. (a): yearly calm frequency (YCF); (b): yearly wind speed (YWS); (c, d): strong wind frequency (SWF1 and SWF2, respectively).
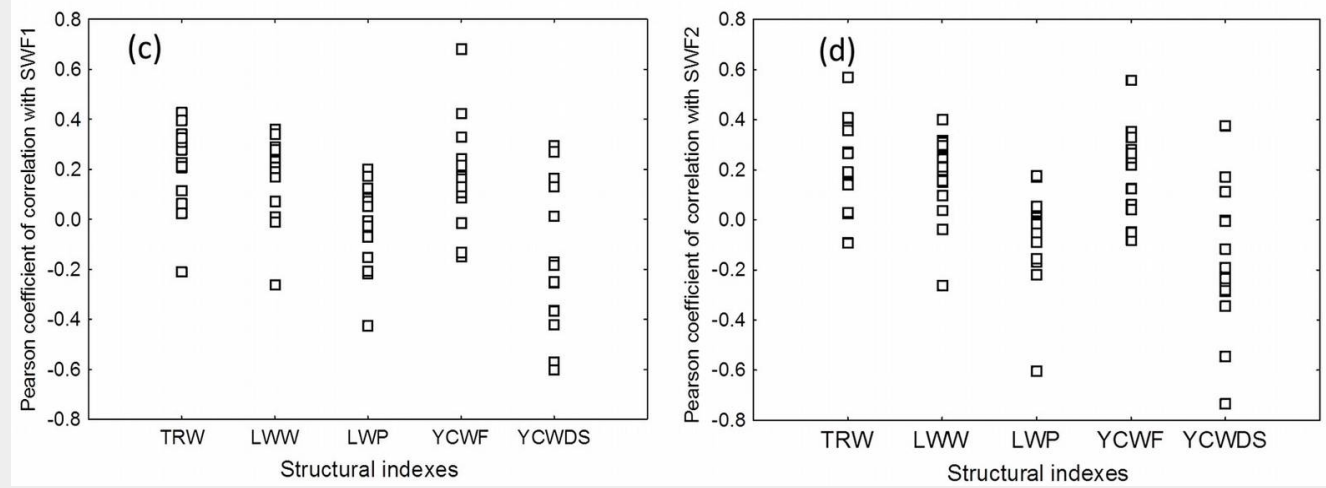

$\left.r_{\text {YCWF TROY,YCF }}=-0.453, p<0.05\right)$. The strong correlation between the fluctuation of $Y C F$ and YCWDS (Fig. 5) suggests that wind may inhibit the differentiation of tracheids in the severest forms of compression wood (e.g., in TROI-E partial $r=0.561$, $\mathrm{p}<0.05)$. This also suggests that the occurrence of compression wood in the investigated trees might not be due to windrelated reasons.

Axial series showed stronger individual correlations with wind variables, that can be summarized as follows: (i) the basal trunk sector had the highest partial correlation between $Y C W D S$ and $S W F(r=0.565$; $\mathrm{p}<0.05$ ); (ii) the 8-12 $\mathrm{m}$ trunk sector showed the strongest partial correlation between YCWF and SWF: $(r=0.597 ; \mathrm{p}<$ 0.05 ); (iii) the $16-20 \mathrm{~m}$ trunk sector exhibited the highest coefficient from all partial correlations between $Y C W D S$ and $Y C F(\mathrm{r}=$ $-0.880 ; p<0.05)$.

\section{Effect of previous-year wind regime}

Fig. 5 summarizes the influence of windrelated parameter values of the preceding calendar years on residual chronologies obtained by removing the influences of temperature and precipitation. Weaker correlations were observed when one-year-lag series were used, especially in the case of strong wind events. A stronger partial correlation between $Y C W F$ and $Y C F$ was obtained using the TROI-E series, while the relationship between YCWF and YWS changed in the TROY-2 and TROY-3 series. The YCWF series that best reflected the annual wind fluctuations were: (i) TROI-E, whose variation strongly reflected the annual wind fluctuation (in terms of both current and previous calendar years); (ii)
TROY-2 and TROY-3, whose fluctuations were consistent with the wind speed of the previous season. In addition, the annual frequency of strong wind days was fairly well reflected by the TROY-2 series. Furthermore, the presence of compression wood along the time series was significantly correlated with: (i) YWS in the TROIA series; (ii) $S W F$ in the TROY-1 series; (iii) $Y W F$ in TROY-2 and especially TROY-5 series.

\section{Effect of intra-seasonal wind regime}

The axial series (TROY) were found to better reflect monthly fluctuations of wind variables compared to core series (TROI Fig. 6), except TROI-D which was significantly correlated with the wind regime (in particular YWS $)$ of December $(r=-0.510, p<$ $0.05)$.

The use of the TROY-7 series increased the partial correlation coefficient between $Y C W D S$ and $Y W S$ to $0.718(\mathrm{p}<0.01)$. Based on this time series, YCWF fluctuations were mainly correlated with the wind regime of June and September of the current year. Contrastingly, based on the time series TROI-E and TROY-3, we found that $Y C W F$ fluctuations were strongly correlated with the wind regime of the following months: (i) December of the previous year; (ii) March of the current year; (iii) May of the current year (Fig. 6). Furthermore, October, November and February of the previous year, as well as May of the current year, appeared to be mostly influencing the amount of the compression wood using the TROY-2 time series.

Regarding the different trunk sections, we noticed that the mild compression wood fractions in the extreme sectors of the bole ( 1 and 7 ) were related to the relatively mild winds of June and February. As for the intermediate height sectors (especially the second sector: 4-8 m), the intensification of wind in March and May was related to the incidence in compression wood (Fig. 6). Moreover, the TROY-2 series presented the largest number of significant correlations with the seasonal wind variables. The fourth trunk section (12-16 m) showed the earliest (May of the preceding calendar year) influence of wind on the occurrence of compression wood (partial correlation coefficient: $-0.455 ; p<0.05)$. Trunk section $7(>28 \mathrm{~m})$ explained $51 \%$ of variation in YCWDS vs. YWS and was mainly with wind regimes in June and September of the previous calendar year.

\section{Anthropogenic interactions}

The analysis of the chosen time series at a decennial scales revealed a stronger relationship with annual fluctuations of wind regimes as compared with the full time series (Fig. 7). For example, wind-related variables accounted for $11.3 \%$ of the variation in YCWF in the TROI-E series over the whole meteorological time series; however, it increased to $99.2 \%$ in 1981-1990.

The first major reduction in stand density due to human interventions occurred in 1969 in sample plot TR6, when trees were 50-150 years old. This density reduction resulted in a larger correlation coefficient between $Y W S$ and $Y C W F$ in the next decade $(r=0.447 v s .0 .137$ in the previous decades). During such decade, precipitation exceeded the multiannual average, though minimally contributed (0.3\%) to the above change. A second major intervention was carried out in 1981-1982, when the 

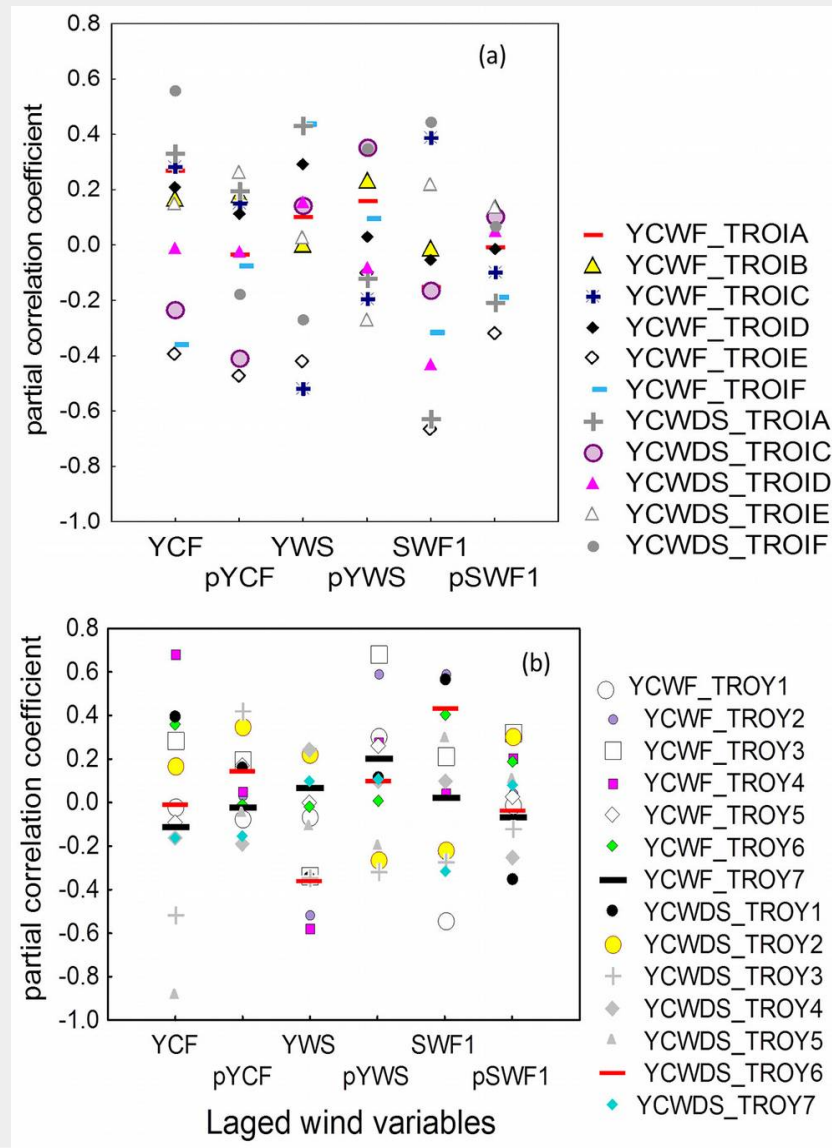

Fig. 5 - Partial correlations between compression wood residual chronologies (after removing the influences of temperature and precipitation) and wind variables in (a) core series (TROI) and (b) disc series (TROY). (YCF, pYCF): current-year and previous-year annual calm frequency; (YWS, pYWS): currentyear and previous-year annual wind speed; (SWF1, pSWF1): current-year and previous-year strong wind frequency.
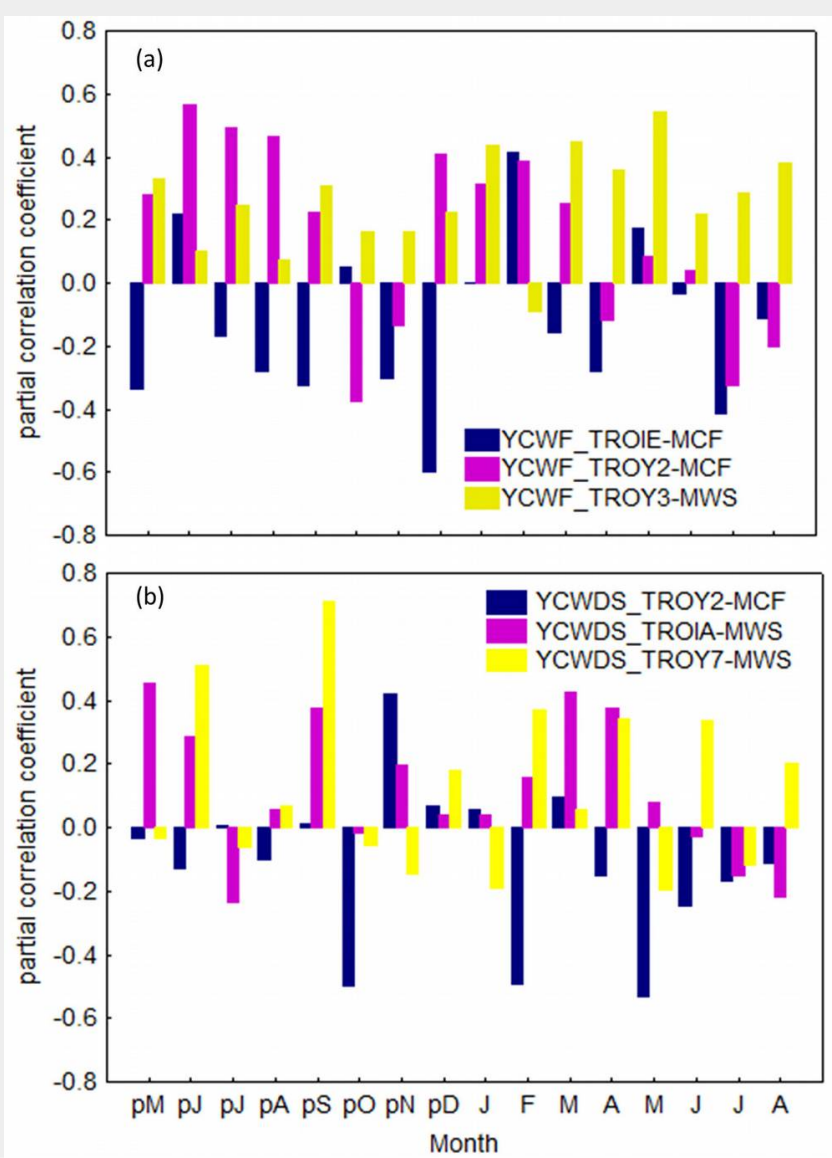

Fig. 6 - Effect of the wind seasonal regime on the annual frequency of compression wood (YCWF - a) and the annual degree of severity of compression wood (YCWDS $-b)$. Months of the previous calendar year are indicated by a " $p$ " in the label. For example, (pM): previous May; $(A)$ : current August.
Fig. 7 - Wind signal in compression wood fluctuations at a yearly $(\mathrm{a}, \mathrm{c})$ and decennial (b, d) scales.
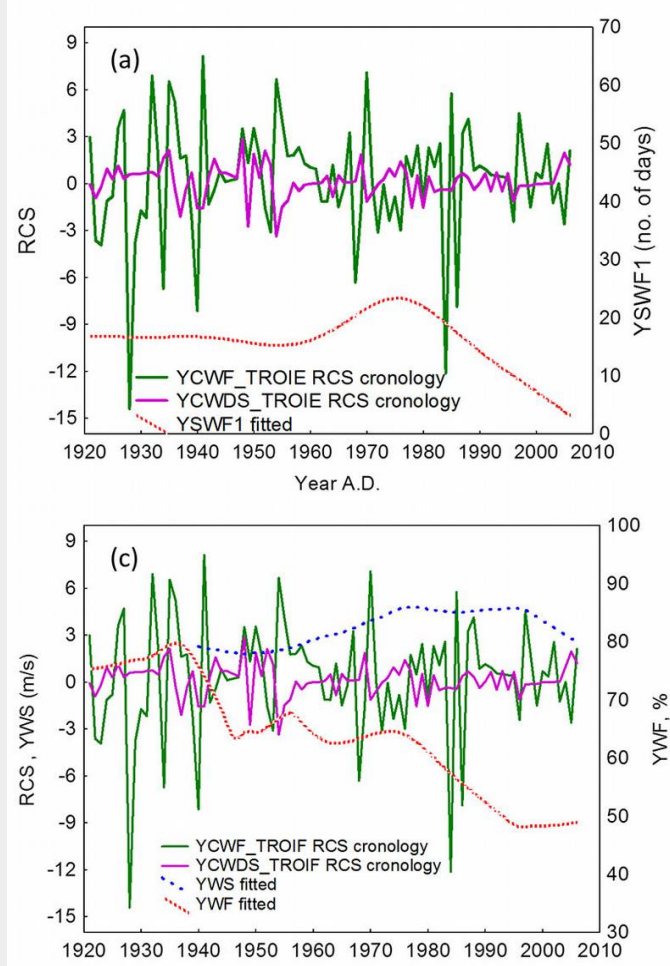

Year A.D.

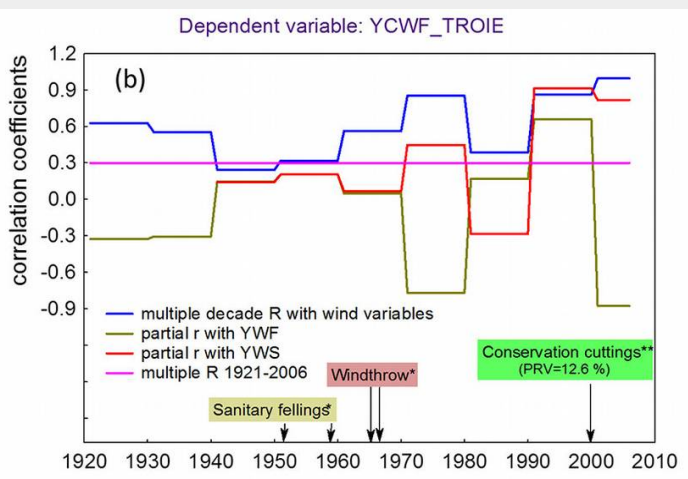

$$
\text { Year A.D. }
$$

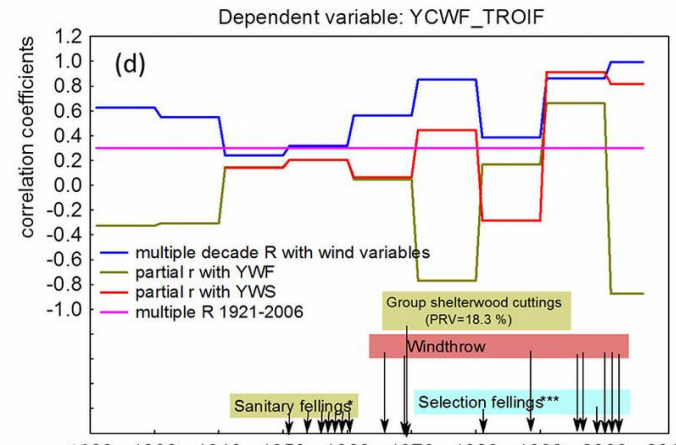

$\begin{array}{llllllllll}1920 & 1930 & 1940 & 1950 & 1960 & 1970 & 1980 & 1990 & 2000 & 2010\end{array}$

Year A.D. 
TR6 stand was subject to the first cuttings aimed at transforming the selection system. During the 1990s, wind speed did not show significant departures from the average values $\left(4.4 \mathrm{~m} \mathrm{~s}^{-1}\right)$, and did not affect the fluctuations in compression wood. The next major intervention occurred in 1999, when the TR6 stand was designated for harvesting. The occurrence of four major storms in the same period (9 January 1998, and 6, 10, and 22 January 1999) threatened the stability of the stand, and led to major windfalls in 2000, 2001, and 2002. As a consequence, $Y C W F$ obtained from the residual trees in TR6 showed a strong variation in YWS.

\section{Discussion}

\section{Dynamic bioaccumulation of compression wood}

It has been reported that peaks in compression wood follow with a certain lag time the peaks in solid precipitation and windstorm events (Cherubini et al. 1996). In this study, the increase in $Y C W D S$ during the 1870 s was related to an increase in air turbulence in Central Europe (Dissescu 1962). The major peak in $Y C W F$ observed in the year 1907 in silver fir populations located in the Brasov Depression reflected their response to a windy winter (Topor 1964). Contrastingly, a decline in the annual amount of compression wood was recorded in 1927-1932 for the same populations as a consequence of a relatively windless period. Further, the peak in $Y C W F$ during 1950 followed the windthrow events occurred in the winter of 1947-1948, which felled trees across 4.5 million $\mathrm{m}^{3}$ in the Eastern Carpathians (Popa 2007). Also, the $Y C W F$ peak during 1956 may be explained by a major snowfall occurred in the previous winter (Mihai 1975). Finally, the strong wind recorded in the 1970 s is reflected by the $Y C W F$ trend (Fig. 7).

The frequency of windthrow events noticeably increased after 1970 throughout Europe (Schelhaas et al. 2003), including Romania (Popa 2007). However, most events in recent decades were not caused by stronger winds (as displayed in Fig. 7), but by the weakening of stand resistance to wind over time, primarily due to human interventions.

\section{Relationship between compression wood and wind regime}

The exploration of historic wind regime at the annual resolution showed that wind perturbations are influenced or accompanied by a long-term intensification of airmass movement. Our results proved that the compression wood is synchronized with the intensity of the wind, rather than with its duration. This study demonstrated that the analysis of the radial growth is an accurate tool in the study of interactions of silver fir populations with moving air masses (Fig. 5). $S W F$ was the wind variable that showed the largest contribution to compression wood formation.

Given that tree stability is conditioned by its underground architecture (Coutts 1983), the rotting of the fulcrum above the gleyic horizon (observed after the uprooting of trees by wind in the TR2 plot) may increase the sensitivity of trees to balance, and explains the high frequency of compression wood in soils on colluvia at the base of slopes (plots TR2 and TR3) or in alluvial deposits (plot TR1). Indeed, the incidence of wood compression at the lowest elevation may be partly explained by the weakening of tree anchoring in hydromorphic soils.

The major wind events (based on fluctuations in $Y C W F$ ) detected through the analysis of the highest altitude time series (e.g., TROI-E) were associated to values observed in December of the previous year (Fig. 6). The comparative examination of the structural detrended series demonstrated the importance of $M C F$ from the previous year in the detection of interannual trends in compression wood incidence $(Y C W F)$, while the trends in compression wood intesity ( $Y C W D S$ ) were better detected by $M C F$ of the current year. The intensity of compression wood, but not its incidence, is explained by the monthly wind regime, especially in the cambial dormancy (previous Septembercurrent March). Duncker \& Spiecker (2005) found that changes in compression wood composition occur with a lag time of one year after the wind perturbation.

The variation of the incidence in compression wood along the trunk (Fig. 4, Fig. 5, Tab. 4) may be explained either by a different sensitivity of receptors of the wind stimulus or by different intensity/duration of the mechanical stress in different parts of the stem. The cytosolic calcium (Du \& Yamamoto 2007), reactive oxygen species (Mori \& Schroeder 2004) and phosphatidylinositol (Strohm et al. 2012) are the molecular mechanoperceptors identified so far. However, the transduction of wind strain in compression wood is mediated by growth hormones produced by the vegetative cones of trees (Kozlowski \& Pallardy 1997), which act as radio-reception antennae. This is in accordance with the quality of the climatic signal (expressed by EPS) we observed in the upper section of the bole (Tab. 4). However, the strongest bond of structural features with atmospheric circulation was identified in the section 16-20 $\mathrm{m}$, which corresponds to the base of the crown in most trees. Indeed, this segment is at the interface between the crown and the trunk, whereby it is likely most contrasting strains and mechanical stress would occur. In this context, the hypothesis of vertical variation of cambium sensitivity to wind stress still holds, though it requires further clarification in future studies.

The in situ molecular reaction to mechanical deformation takes minutes (Martin et al. 2009), while basipetal hormonal transmission of wind stimulus requires a longer time. Considering wind conditions at the monthly scale, the closer correlations with the chronologies of compression wood (Fig. 6) suggest that its induction is faster in trees exposed to a higher wind frequency rather than to a greater wind speed. Moreover, the positive and significant relationship of $Y C W F$ and $Y C F$ (Fig. 5) suggests that higher wind speed inhibits the transduction of wind stimuli in compression wood. Thus, it can be hypothesized that this process is delayed in periods of atmospheric calm, and this would support by the modest correlation with wind variables observed in March (Fig. 6), which was in fact the most turbulent month. Based on these observations, we speculate that the wind stimulus must continue for 24 months to exceed the excitation threshold, leading to the formation of compression wood.

\section{Anthropogenic interferences}

In this study, $61 \%$ of the explored series failed to explain the effect of climatic variables on the incidence of compression wood, suggesting the existence of different sources of variation. A continuous improvement over time of the relationship between the incidence of compression wood and wind-related variables at a decennial scale was observed in the TROI-E and TROI-F time series (Fig. 7). In the latter series this relationship may be the consequence of the exposure of remnant trees to wind action by the progressive reduction in stand density, while in the TROI-E series it might be related to the continuous intensification of wind, as reflected by $Y W S$ averages in the last eight decades (Fig. 7). This hypothesis is supported by the synchronization of the maximum magnitude of the correlation with peaks in $Y W S$ and $S W F$ at a decennial scale (Fig. 7). Conversely, weaker relationships were found in periods of relative atmospheric stability. Thus, it may be argued that compression wood formation in trees is promoted by high-intensity wind events, while other factors drive xylogenetic processes during relative atmospheric calm periods.

Stand thinning increased the incidence of $Y C W F$ as a consequence of the increased frequency of windthrows. Sheltered trees tend to form compression wood all around the stem in the shape of circular crowns within the juvenile wood (Timell 1986), as observed in felled trees (Dinulica 2008). In addition, thinning exposes stand edges to high wind speeds (Zeng et al. 2004), thus affecting the subsequent existence of survivors (Zielonka \& Malcher 2009). Indeed, the sap flow performance of survivors is reduced due to the narrowing of the hydroactive section (Ueda \& Shibata 2004). The narrow tracheids of the compression wood (Yoshizawa \& Idei 1987) react better to their new physiological status.

The instability of the correlation between $Y C W F$ and wind variables after the 1969 
intervention in the TR2 plot (Fig. 7d) suggests that the recovery time of the canopy was affected. The decrease in competition stimulates crown growth and the formation of compression wood through knots (Wedel et al. 1968). Moreover, radial growth after thinning may be accompanied by the occurrence of compression wood (Cown et al. 1992), though contrasting results have been reported in the literature (Young et al. 1991). Moreover, it has been reported that stand density does not affect the total content in compression wood of Sitka spruce trees, though the increased competition may increase its severe fraction (EUCWP 2004). In this study, the effect of strong human interventions on wood structure of silver fir trees in the plot TR6 did not appear to exceed a decade (Fig. 7d). In maritime pine, stand thinning only affected the formation of compression wood for 18 years (Radi \& Castera 1992).

Despite the decline in the frequency of strong windstorms in the last 150 years (Schütz 2004), the precarious stability of forests to wind action calls for silvicultural practices aimed at optimizing the competition among trees, to improve individual and group resistance and minimize the incidence of compression wood.

\section{Conclusions}

This study demonstrates that wind affects radial growth of silver fir trees, even in habitats where wind is not a limiting factor for growth. Peaks of incidence in compression wood were synchronous with increases in air turbulence over the period 1921 to present.

The non-detrended time series of compression wood showed a high degree of internal dependence, which emphasized the persistence of climatic excitation in the compression wood records and led to the analysis of the previous calendar year contributions. The analysis of standardized series showed the influence of wind conditions in the preceding year on the incidence of the compression wood, while its intensity is better correlated with the wind regime in the current year.

The response of trees to fluctuations in wind conditions varied in space, even at relatively low distances. Trees growing at higher elevation showed a stronger wind effect in the time series of compression wood. At the lowest altitude, wood compression may be explained by the weakening of tree anchoring in hydromorphic soils.

Variation of the incidence of compression wood along the trunk suggests that cambium sensitivity to wind-induced mechanical stress varies or the transduction of wind load in woody tissue changes in different part of the stem. Based on our results, the trunk section at the base of the crown $(16-20 \mathrm{~m})$ better reflects annual wind movements, while the incidence of compression wood at height of 4-8 m reflects monthly wind circulation.

On a monthly scale, wind conditions in previous December, current March and current May stimulate the occurrence of compression wood, whereas those in previous September, current February and current May affect its intensity.

The analysis of residual chronologies of compression wood at the decennial scale showed that fluctuations in cambium capacity reflect long-term wind conditions, and revealed that wind strongly contributed to the formation of compression wood up to a decade after human interventions.

\section{List of abbreviations}

- $A C F$ : Autocorrelation function

- EPS: Expressed population signal

- ESR: Edmund Schulman's correlation coefficient

- EWP: Earlywood percentage (of the total ring width)

- $E W W$ : Earlywood width (mm)

- $L W P$ : Latewood percentage

- $L W W$ : Latewood width (mm)

- MCF: Monthly average frequency of the calm periods (\%)

-Msc: Mean sensitivity of the mean chronology

- MWF: Monthly average frequency of the wind periods (\%)

- MWS: Monthly average wind speed (m $\left.\mathrm{s}^{-1}\right)$

-PACF: Partial AutoCorrelation Function

- REFF: Effective chronology signal

- $S W F 1$ : Average number of days with high speed wind $\left(\geq 11 \mathrm{~m} \mathrm{~s}^{-1}\right)$ classified by the minimum daily frequency (at least one case in four) of the meteorological records (n)

- $S W F 2$ : Average number of days with high speed wind $\left(\geq 11 \mathrm{~m} \mathrm{~s}^{-1}\right)$ classified by the average daily speed of the wind ( $n$ )

- $T R W$ : Total ring width ( $\mathrm{mm})$

- YCF: Yearly average frequency of the calm period (\%)

- YCWDS: Yearly compression wood degree of severity

- YCWF: Yearly frequency of compression wood (\%)

- YWF: Yearly monthly average frequency of the wind period (\%)

- YWS: Yearly average wind speed $\left(\mathrm{m} \mathrm{s}^{-1}\right)$

\section{Acknowledgements}

This work was supported by the Romanian Executive Agency for Higher Education, Research, Development and Innovation Funding (Project number TD-79: "Structural macroscopic features of raw wood as a means of estimating its quality"). We thank Eng. Laurentiu Puscasu for assisting with the field work. We also thank the two anonymous referees for providing constructive remarks.

\section{References}

Box GEP, Jenkins GM, Reinsel GR (2008). Time series analysis: forecasting and control. John Wiley and Sons, Hoboken, New Jersey, USA, pp. 784.

Butler DR, Sawyer CF (2008). Dendrogeomorphology and high-magnitude snow avalanches: a review and case study. Natural Hazards and Earth System Sciences 8: 303-309. - doi: 10.5194/nhess-8-303-2008

Cherubini P, Piussi P, Schweingruber F (1996). Spatiotemporal growth dynamics and disturbances in a subalpine spruce forest in the Alps: a dendroecological reconstruction. Canadian Journal of Forest Research 26: 991-1001. - doi: 10.1139/×26-109

Cook ER, Briffa K (1992). Data analysis. In: "Methods of Dendrocronology" (Cook ER, Kairiukstis E eds). Kluwer Academic Publishers, Dordrecht, Boston, London, UK, pp. 97-162.

Cook ER, Pederson N (2011). Uncertainty, emergence and statistics in dendrocronology. In: "Dendroclimatology. Progress and Prospects" (Hughes MK, Swetnam TS, Diaz HF eds). Springer Science+Business Media B.V., Dordrecht, Netherlands, pp.77-112. - doi: 10.1007/97 8-1-4020-5725-0 4

Coutts MP (1983). Root architecture and tree stability. Plant and Soil 71: 171-188. - doi: 10.1007/ BF02182653

Cown DJ, Young GD, Burdon RD (1992). Variation in wood characteristics of 20-year-old half-sib families of Pinus radiata. New Zealand Journal of Forest Science 22 (1): 63-76. [online] URL: http://www.researchgate.net/publication/2574 09533

Dinulica F (2005). Cercetari privind incidenta lemnului de compresiune la brad [On the silver fir compression wood]. Proceedings of the Symposium "Forest and Sustainable Development". Transilvania University Press, Brasov, Romania, pp. 317-322. [in Romanian]

Dinulica F (2008). Cercetari privind factorii de influenta asupra formarii lemnului de compresiune la brad [Researches on the influencing factors on silver fir compression wood formation]. PhD Thesis, Transilvania University, Brasov, Romania, pp. 236. [in Romanian]

Dissescu R (1962). Frecventa daunelor produse de vant si esalonarea masurilor amenajistice de protectie [The frequency of wind damage and planning of the protection measures]. Revista Padurilor 77 (10): 611-614. [in Romanian]

Du SH, Yamamoto F (2007). An overview of the biology of reaction wood formation. Journal of Integrative Plant Biology 49: 131-143. - doi: 10.1111/j.1744-7909.2007.00427.x

Duncker P, Spiecker H (2005). Compression wood formation and pith eccentricity in Picea abies L. depending on the selected site-factors: detection of compression wood by its spectral properties in reflected light. In: Proceedings of the DendroSymposium 2004 "TRACE - Tree Rings in Archaeology, Climatology and Ecology, Vol. 3" (Gärtner H, Esper J, Schleser G eds). Birmensdorf (Switzerland) 22-24 Apr 2004. Schriften des Forschungszentrums Jülich, Reihe Umwelt 53: 150-158. [online] URL: http:// www.researchgate.net/publication/30046563

Duncker P, Spiecker H (2008). Cross-sectional compression wood distribution and its relation to eccentric radial growth in Picea abies Karst. Dendrochronologia 26: 195-202. - doi: 10.1016/j. dendro.2008.06.004

Enoos AR (1999). The aerodynamics and hydrod- 
inamics of plants. Journal of Experimental Biology 202: 3281-3284.

EUCWP (2004). Compression wood in conifers. The characterisation of its formation and its relevance to timber quality. QLK5-CT-2001-00177 Final report, pp. 379. [online] URL: http://my. sosius.com/forestry/live_projects/wood_and_ti mber_properties/compression_wood_project/c ompression_wood_final_report.pdf?ref $=16423$ 329-1

Geiger R, Aron RH, Todhunter P (2003). The climate near the ground. Rowman and Littlefield Publishers Inc., Lanham Boulder, New York, USA, pp. 91-100.

Grissino-Mayer HD, Miller DL, Mora Cl (2010). Dendrotempestology and the isotropic record of tropical cyclones in tree rings of the Southeastern Unites States. In: "Tree Ring and Natural Hazards. A State-of-the-Art" (Stoffel $M$, Bollschweiler M, Butler DR, Luckman BH eds). Springer, Dordrecht, Heidelberg, London, New York, pp. 291-304.

Gruber A, Baumgartner D, Zimmermann J, Oberhuber W (2009). Temporal dynamic of wood formation in Pinus cembra along the alpine treeline ecotone and the effect of climate variables. Trees 23: 623-635. - doi: 10.1007/s00468008-0307-7

Harris JM (1977). Shrinkage and density of radiata pine compression wood in relation to its anatomy and mode of formation. New Zeeland Journal of Forest Science 7 (1): 91-106. [online] URL: http://www.scionresearch.com/_data/as sets/pdf_file/0017/37520/NZJFS711977-106.pdf Helliwell R (2004). Uneven-aged silviculture. In: "Encyclopedia of Forest Sciences" (Burley J, Evans J, Youngquist JA eds). Elsevier Ltd., Oxford, UK, pp. 1073-1077.

Kozlowski T, Pallardy SG (1997). Growth control in woody plants. Academic Press, London, UK, pp. 383. [online] URL: http://books.google. com/books?id=BwP4lAPBykcC

Low AJ (1964). A study of compression wood in Scots pine (Pinus sylvestris L.). Forestry 37: 179201. - doi: 10.1093/forestry/37.2.179

Lutgens FK, Tarbuck EJ (2013). The atmosphere. An introduction to meteorology (12 ${ }^{\text {th }}$ edn). Prentice Hall, New Jersey, USA, pp. 528.

Macdonald E, Hubert J (2002). A review of the effects of silviculture on timber quality of Sitka spruce. Forestry 75: 107-138. - doi: 10.1093/for estry/75.2.107

Marcu M, Huber V, Chitea G (2006). Cercetari privind distributia spatio-temporala a precipitatiilor în regiunile muntoase (Muntii Brasovului) [Researches on the spatio-temporal distribution of rainfall in the mountainous area (the mountains surrounding Brasov region)]. Silvologie 5: 190-205. [in Romanian]

Marcu-Huber V (2001). Influenta reliefului muntos asupra circulatiei atmosferice în zona Carpatilor de Curbura [Mountainous ground influence on the air circulation in the Curvature Carpathians Region]. Revista de Silvicultura 6 (13-14): 22-26. [In Romanian]

Martin L, Leblanc-Fournier N, Azri W, Lenne C, Henry C, Coutand C, Julien JL (2009). Characterization and expression analysis under bending and other abiotic factors of PtaZFP2, a poplar gene encoding a Cys2/Hisz zinc finger protein. Tree Physiology 29: 125-136. - doi: 10.1093/tree phys/tpno11

Mihai E (1975). Depresiunea Brasov. Studiu climatic [Brasov depression. Climatic study]. Romanian Academy Publishing House, Bucharest, Romania, pp. 209. [In Romanian]

Mori IC, Schroeder JI (2004). Reactive oxygen species activation of plant $\mathrm{Ca}^{2+}$ channels. Signaling mechanisms in polar growth, hormone transduction, stress signaling, and hypothetically mechanotransduction. Plant Physiology 135: 702-708. - doi: 10.1104/pp.104.042069

Nicolescu NV (2014). Silvicultura II: Silvotehnica. [Silviculture II: Forest operations]. Aldus Publishing House, Brasov, Romania, pp. 289. [in Romanian]

Panayotov M, Yurukov S (2005). Dendroecological analysis of the influence of strong winds and snow accumulation on the growth of trees at the treeline in Vitosha Mountain, Bulgaria. In: Proceedings of the DendroSymposium 2005 "TRACE - Tree Rings in Archaeology, Climatology and Ecology, Vol. 4" (Heinrich I, Gärtner H, Monbaron M, Schleser $G$ eds). Fribourg (Switzerland) 21-23 Apr 2005. Schriften des Forschungszentrums Jülich, Reihe Umwelt 61: 165-174. [online] URL: http://www.research gate.net/publication/30046596

Pillow MY (1931). Compression wood records hurricane. Journal of Forestry 29: 575-578. [online] URL: http://www.ingentaconnect.com/ content/saf/jof/1931/00000029/00000004/artoo 020

Popa I (2007). Managementul riscului la doboraturi produse de vant [Risk management at windthrow]. Tehnica Silvica Publishing House, Bucharest, Romania, pp. 33-47. [in Romanian]

Radi M, Castera P (1992). Qualification de la forme de deux pin maritimes en liaison avec la structure de leur bois [Qualifying the shape of two maritime pine trees (Pinus pinaster) in connexion with their wood structure]. Annals of Forest Science 49: 185-200. [In French] - doi: 10.1051/forest:19920207

Read J, Stokes A (2006). Plant biomechanics in a ecological context. American Journal of Botany 93: 1546-1565. - doi: 10.3732/ajb.93.10.1546 Robertson A (1990). Directionality of compression wood in balsam fir wave forest trees. Canadian Journal of Forest Research 20 (8): 11431148. - doi: 10.1139/x90-152

Schelhaas MJ, Nabuurs GJ, Schuck A (2003). Natural disturbances in the European forests in the 19th and 20th centuries. Global Change Biology 9: 1620-1633. - doi: 10.1046/j.1365-2486.2003.00 684.x

Schweingruber $\mathrm{FH}$ (2007). Wood structure and environment. Springer-Verlag, Berlin Heidelberg New York, pp. 279. [online] URL: http:// books.google.com/books?id=t5fVEqRnyjoC

Schütz JP (2004). Stabilité au vent des hêtraies: les enseignements de la tempête de 1999 dans le nord-est de la France [Wind resistance of beech groves: lessons learned from the 1999 storm in the north-east of France]. RDV techniques 3: 21-28. [In French]

Shelbourne CJA, Ritchie K (1968). Relationship between degree of compression wood development and specific gravity and tracheid characteristics in loblolly pine (Pinus taeda L.). Holzforschung 22: 185-190. - doi: 10.1515/hfsg.1968.2 2.6.185
Sheskin DJ (2004). Hanbook of parametric and nonparametric statistical procedures $\left(3^{\text {rd }} \mathrm{edn}\right.$ ). Chapman\&Hall/CRC, Boca Raton, London, New York, Washington, pp. 1182.

Stoffel M, Bollschweiler M (2008). Tree-ring analysis in natural hazards research - an overview. Natural Hazards Earth System Science 8: 187202. - doi: 10.5194/nhess-8-187-2008 Strohm AK, Baldwin KL, Masson PH (2012). Multiple roles for membrane-associated protein trafficking and signaling in gravitropism. Frontiers in Plant Science 3: 274.

Telewski FW (1989). Structure and function of flexure wood in Abies fraseri. Tree Physiology 5: 113-121. - doi: 10.1093/treephys/5.1.113

Timell TE (1986). Compression wood in Gymnosperms. Springer Verlag, Berlin Heidelberg New York, pp. 2150. [online] URL: http://www. cabdirect.org/abstracts/19870614730.html Topor N (1964). Ani ploiosi si secetosi în R.P. Romîna [Rain and drought years in Romania]. C.S.A. Institutul Meteorologic, Bucharest, Romania, pp. 304. [In Romanian]

Ueda M, Shibata E (2004). Why do trees decline or dieback after a strong wind? Water status of Hinoki cypress standing after typhoon. Tree Physiology 24: 701-706. - doi: 10.1093/treephys/ 24.6.701

Wedel Von KW, Zobel BJ, Shelbourne CJA (1968). Prevalence and effects of knots in young loblolly pine. Forest Products Journal 18: 97-103.

Wimmer R, Johansson M (2014). Effects of reaction wood on the performance of wood and wood-based products. In: "The biology of reaction wood" (Gardiner B, Barnett J, Saranpää P, Gril J eds). Springer Verlag, Berlin-Heidelberg, Germany, pp. 225-274. - doi: 10.1007/978-3-64210814-3 8

WinDENDRO (2007). WinDENDROTM2006 for tree-ring analysis. Manual of exploitation. Régent Instruments Inc., Québec City, Canada, pp. 133.

WRB (1998). World reference base for soil resources. World Soil Resources 84, FAO, Rome, Italy, pp. 88.

Yoshizawa N, Idei T (1987). Some structural and evolutionary aspects of compression wood tracheids. Wood and Fiber Science 19: 343-352. [online] URL: http://cat.inist.fr/?aModele=affich eN\&cpsidt $=7780855$

Young GD, McConchie DL, McKinley RB (1991). Utilisation of 25-year-old Pinus radiata. Part 1: wood properties. New Zealand Journal of Forestry Science 21 (2-3): 217-227. [online] URL: http://www.scionresearch.com/_data/assets/p df_file/0010/17785/NZJFS212_31991YOUNG217227.pdf

Zeng $\mathrm{H}$, Peltola $\mathrm{H}$, Talkkari $\mathrm{A}$, Venäläinen $\mathrm{A}$, Strandman H, Kellomäki S, Wang K (2004). Influence of clear-cutting on the risk of wind damage at forest edges. Forest Ecology and Management 203: 77-88. - doi: 10.1016/j.foreco. 2004.07.057

Zielonka T, Malcher P (2009). The dynamics of mountain mixed forest under wind disturbances in the Tatra Mountains, central Europe a dendrochronlogical reconstruction. Canadian Journal of Forest Research 39 (11): 2215-2223. doi: 10.1139/Xo9-130 